\title{
Recent progress in long-term stability of perovskite solar cells
}

\author{
Seyedali Emami, Luísa Andrade, ${ }^{1}$ Adélio Mendes \\ LEPABE - Laboratory for Process Engineering, Environment, Biotechnology and Energy \\ Engineering, Faculdade de Engenharia da Universidade do Porto. ${ }^{1}$ (mendes@fe.up.pt)
}

\begin{abstract}
Perovskite solar cells made a huge breakthrough among the nanostructured thin film photovoltaics. They exhibited certified power conversion efficiency (PCE) as high $24 \%$ in 2015. A vast amount of research were spent on improvement of PCE and lowering the fabrication process temperature, resulting in outstanding outcomes in these areas. In contrast, the long-term stability and commercialization of these devices were not well studied. The review briefly summaries the challenges of perovskite solar cells in the road of stabilization and commercialization.
\end{abstract}

Subject Headings. Photovoltaic Cell, Solar Energy.

Author Keywords. Perovskite Solar Cell, Stability, Long-Term, Commercialization.

\section{Introduction}

Solar energy is the most reliable renewable energy sources to replace traditional energy resources such as coal, oil and natural gas. In this context, solar cells have gained tremendous attentions during past decades. To date, silicon solar cells are the most common photovoltaic devices on the market. The high power conversion efficiency of around $25 \%$ is the major advantage of silicon solar cells which makes them the leader in the market(Green et al. 2015). High production costs and complex manufacturing of Si-based photovoltaics, are the drawback of these devices.

Thin-film solar cells are the next generation in line, solar cells such as copper indium gallium selenide (CIGS) with efficiencies reaching $20 \%$ (Jackson et al. 2011), and cadmium telluride (CdTe) photovoltaics (Britt and Ferekides 1993) are the most famous devices of this type. The production process of these cells involves high temperature, toxic raw materials, and high cost vacuum vapor deposition. Therefore, these types of photovoltaics may not grow into the market higher than their current share.

Emerging solar cells are the most recent devices in the research field. Dye-sensitized solar cells (DSCs) are the pioneer in this group. The first DSC was reported on 1991 (O'Regan and Grätzel 1991) which opened the doors to low-cost and easy roll-to-roll fabrication solar cell technology. Commonly, dye-sensitized solar cells are consist of a photoanode (e.g., $\mathrm{TiO}_{2}$ ), a dye (e.g., N719), an electrolyte (e.g., iodide/triiodide redox couple), and a counter electrode (e.g., platinum). DSCs working principle is different from common $p-n$ junction solar cells, since light adsorption and charge transport occur separately at dye sensitizer and photoanode. The generated electrons are transported to the conduction band of the photoanode, and the electrolyte delivers the holes to the counter electrode(Hagfeldt et al. 2010). Conventional dyesensitized solar cells were constructed with liquid-state electrolytes and they have reached to PCE near to $13 \%$ with cobalt-based redox shuttle and an engineered donor- $\pi$-acceptor dye (Mathew et al. 2014). The biggest challenge for DSC is to improve their long-term stability. The most common issues are including degradation of photoanode and counter electrode, concentration drop in electrolyte redox couple, and encapsulation related concerns (Asghar 
et al. 2010). Stability issues related to temperature, electrolyte leaking, and moisture presence in the cell could be reduced through suitable encapsulation of the liquid-state electrolyte DSC devices (Ribeiro et al. 2012). In contrast, the liquid electrolyte of DSCs could be replaced with solid state organic hole transport material (HTM) to minimize the stability issues(Bach et al. 1998). The power conversion efficiency of solid-state DSCs were relatively lower than the conventional liquid ones. To date, the highest PCE reported for solid-state DSCs is around $6 \%$ with 2,2',7,7'-tetrakis( $\mathrm{N}, \mathrm{N}$-dimethoxyphenylamine)-9,9'- spirobifluorene (spiro-OMeTAD) as the organic HTM and C220 dye (Cai et al. 2011).

On 2009 Miyasaka and co-authors, were reported the first application of organometal halide perovskite materials in photochemical solar cells (Kojima et al. 2009). The device had a structure similar to DSCs, photoanode of $\mathrm{TiO}_{2}, \mathrm{CH}_{3} \mathrm{NH}_{3} \mathrm{PbX}$ (where $\mathrm{X}=\mathrm{Br}$, I) perovskite as light harvesting agent, iodide/triiodide redox couple as electrolyte, and platinum for counter electrode. The best working cell had PCE of $3.81 \%$, but it was quite unstable when exposing to air. This pioneer work lead the research to focus more on organometal halide perovskite and to date, more stable cells with certified PCE as high as $24 \%$ has reported (Green et al. 2015).

Research has mainly dedicated to improving the power conversion efficiencies of perovskite solar cells (PSCs) while less attentions were focused on stability, lead content and commercialization issues of this new type of devices. Therefore, a brief review of these challenges is presented in this review.

\section{Working principle of perovskite solar cells}

Perovskite is a term used for referring to a crystal structure identical to calcium titanium oxide $\left(\mathrm{CaTiO}_{3}\right)$. The mineral was first discovered in Russia and it is named after Russian mineralogist, Count Lev Alekseevich Perovskii (1792-1856). The general chemical formula for perovskite is $A M X_{3}$, where " $A$ " and " $M$ " are cations of very different sizes, and " $X$ " is an anion. Organometal halide perovskites containing cation metal of carbon family (such as $\mathrm{Ge}^{2+}, \mathrm{Sn}^{2+}$, and $\mathrm{Pb}^{2+}$ ) and anion halogens $(\mathrm{F}, \mathrm{Cl}, \mathrm{Br}$, and $\mathrm{I})$ are of the most interest for their good photovoltaic application (Mitzi 1996). The most common organic compound used for perovskite solar cells are; methylammonium $\left(\mathrm{CH}_{3} \mathrm{NH}_{3}^{+}\right)$, ethylammonium $\left(\mathrm{CH}_{3} \mathrm{CH}_{2} \mathrm{NH}_{3}{ }^{+}\right)$, and formamidinium $\left(\mathrm{NH}_{2} \mathrm{CH}=\mathrm{NH}_{2}{ }^{+}\right.$) (Kim et al. 2012, Hao et al. 2014, Im et al. 2012). Perhaps the most common perovskites used in photovoltaic applications are methylammonium lead triiodide $\left(\mathrm{CH}_{3} \mathrm{NH}_{3} \mathrm{Pbl}_{3}\right)$ or others with mixed halides structures $\left(\mathrm{CH}_{3} \mathrm{NH}_{3} \mathrm{Pbl}_{3-x} \mathrm{Br}_{x}\right.$ or $\left.\mathrm{CH}_{3} \mathrm{NH}_{3} \mathrm{Pbl}_{3-\mathrm{x}} \mathrm{Cl}_{x}\right)$ (Green, Ho-Baillie, and Snaith 2014, Ball et al. 2013).

Working principle of a solar cell involves, light absorption, charge separation, charge transport, and charge collection. Organometallic perovskites such as $\mathrm{CH}_{3} \mathrm{NH}_{3} \mathrm{Pbl}_{3}$ have showed both electron and hole transport properties (Xing et al. 2013). Therefore, perovskite solar cells could be constructed both as $p-n$ junction and $p-i-n$ junction. Perovskite cells are typically fabricated with two structures; mesoporous and planar.

The structure of mesoporous perovskite cells (Figure 1a) includes a mesoporous metal oxide (e.g., $\mathrm{TiO}_{2}, \mathrm{Al}_{2} \mathrm{O}_{3}$ ) which is coated with perovskite sensitizer. In contrast, planar perovskite solar cell architecture (Figure $1 \mathrm{~b}$ ) involves a perovskite layer deposited between electron and hole transport materials. Comparing these two structures, recombination rate of planar configuration is lower than mesoporous cells while, the charge transport rate of them was similar (Gonzalez-Pedro et al. 2014). Planar structure cells are interesting for flexible cells since their fabrication does not involve typical high temperature sintering stages. Apart from these 
two configurations, an HTM-free structure was also reported with moderate power conversion efficiencies reaching to $12.8 \%$ (Mei et al. 2014).

(a)

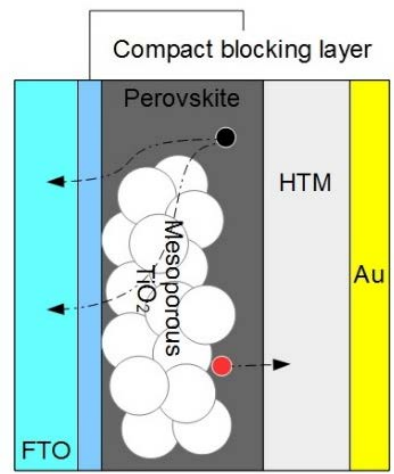

(b)

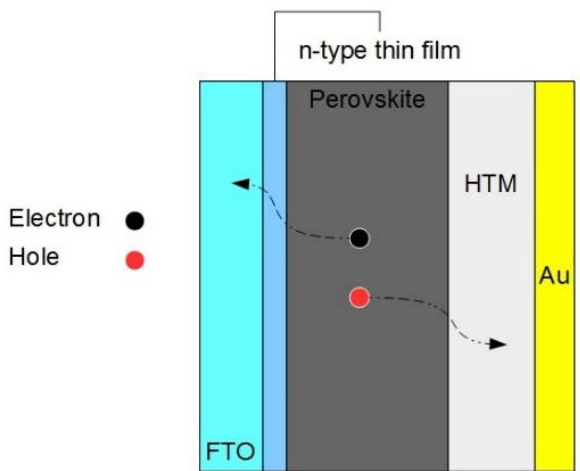

Figure 1: Schematic illustration of (a) mesoporous perovskite solar cell with $\mathrm{TiO}_{2}$ layer as electron transport material; (b) planar perovskite structure in which perovskite acts as ambipolar transport

The energy level for mesoporous perovskite constructed with $\mathrm{TiO}_{2} / \mathrm{CH}_{3} \mathrm{NH}_{3} \mathrm{Pbl} / 3$ spiroOMeTAD/Au junction is well matched for charge transport and separation (Figure 2a). For similar mesoporous configuration the electron transfer process involves (Figure $2 \mathrm{~b}$ ) (Marchioro et al. 2014):

Photoexcitation of perovskite;

$$
\text { Perovskite }+\mathrm{h} v \rightarrow\left(\mathrm{e}^{-} \cdots \mathrm{h}^{+}\right) \text {perovskite }
$$

Electron injection;

Hole injection;

$$
\begin{gathered}
\left(\mathrm{e}^{-} \cdots \mathrm{h}^{+}\right)_{\text {perovskite }} \rightarrow \mathrm{e}_{\mathrm{cb}}^{-}\left(\mathrm{TiO}_{2}\right)+\mathrm{h}^{+}(\text {perovskite }) \\
\mathrm{h}^{+}(\text {perovskite }) \rightarrow \mathrm{h}^{+}(\mathrm{HTM})
\end{gathered}
$$

$$
\begin{gathered}
\left.\left(\mathrm{e}^{-} \cdots \mathrm{h}^{+}\right)_{\text {perovskite }} \rightarrow \mathrm{h}^{+}(\mathrm{HTM})+e^{-} \text {(perovskite }\right) \\
\left.\mathrm{e}^{-} \text {(perovskite }\right) \rightarrow \mathrm{e}_{\mathrm{cb}}^{-}\left(\mathrm{TiO}_{2}\right)
\end{gathered}
$$

Photoluminescence;

$$
\left(\mathrm{e}^{-} \cdots \mathrm{h}^{+}\right)_{\text {perovskite }} \rightarrow \mathrm{h} v
$$

Non-radiative recombination;

$$
\left(\mathrm{e}^{-} \cdots \mathrm{h}^{+}\right)_{\text {perovskite }} \rightarrow \nabla
$$

Back electron transfer at TiO2-pervoskite junction;

$$
\mathrm{e}_{\mathrm{cb}}^{-}\left(\mathrm{TiO}_{2}\right)+\mathrm{h}^{+} \text {(perovskite) } \rightarrow \nabla
$$

Back charge transfer at perovskite-HTM junction;

$$
\mathrm{h}^{+}(\mathrm{HTM})+e^{-} \text {(perovskite) } \rightarrow \nabla
$$

Charge recombination at $\mathrm{TiO}_{2}-\mathrm{HTM}$ interface;

$$
\mathrm{e}_{\mathrm{cb}}^{-}\left(\mathrm{TiO}_{2}\right)+\mathrm{h}^{+}(\mathrm{HTM}) \rightarrow \nabla
$$

The overall photovoltaic conversion efficiency of mesoporous structure perovskite cell is controlled through above processes. In order to achieve high PCE, charge generation and transport (1)-(3) should have faster rate comparing to undesired recombination (4)-(8). 
(a)

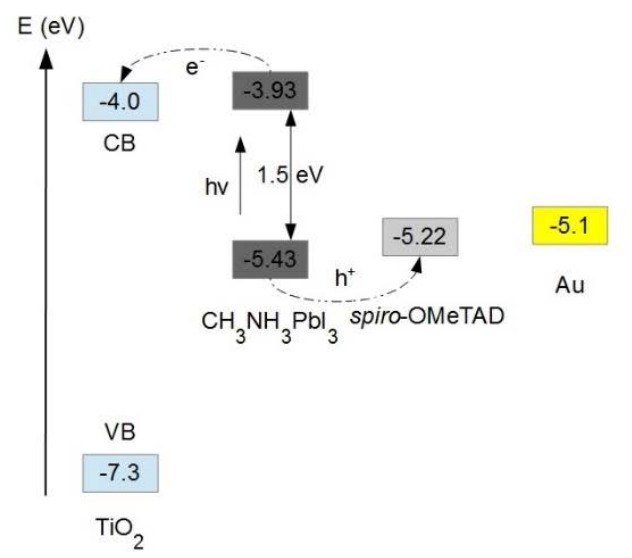

(b)

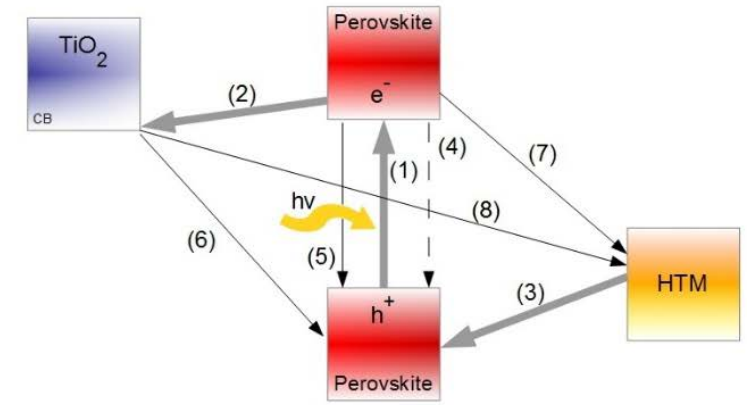

Figure 2: (a) Vacuum energy levels for perovskite cell with $\mathrm{TiO}_{2} / \mathrm{CH}_{3} \mathrm{NH}_{3} \mathrm{Pbl} / 3$ spiro-OMeTAD/Au configuration. (b) Electron and hole transport process for mesoporous perovskite

The ideal bandgap for single-junction photovoltaic cell should be ranging from 1.1 to $1.4 \mathrm{eV}$ (Meillaud et al. 2006). One of the most remarkable properties of perovskite material is that they could adopt different bandgaps by varying their composition. For instance, by changing the halide composition of $\mathrm{CH}_{3} \mathrm{NH}_{3} \mathrm{~Pb}\left(\mathrm{I}_{1-\mathrm{x}} \mathrm{Br} \mathrm{r}_{3}\right.$ (where, $0 \leq \mathrm{x} \leq 1$ ), the bandgap could be altered from 1.2 to $2.3 \mathrm{eV}$ (Figure 1a) (Noh et al. 2013). Alternatively, Snaith et al. showed that by increasing the cation size $\mathrm{APbl}_{3}$ perovskites, the bandgap could decrease. They have explored the change in bandgap energy and absorbance at UV-Vis spectra for three perovskite structure by substituting large radius formamidinium with slightly smaller methylammonium and very small cesium (Figure 1b) (Eperon et al. 2014).

a

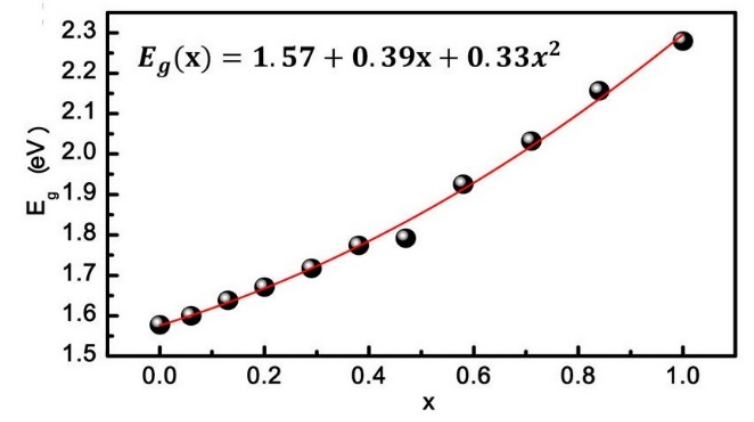

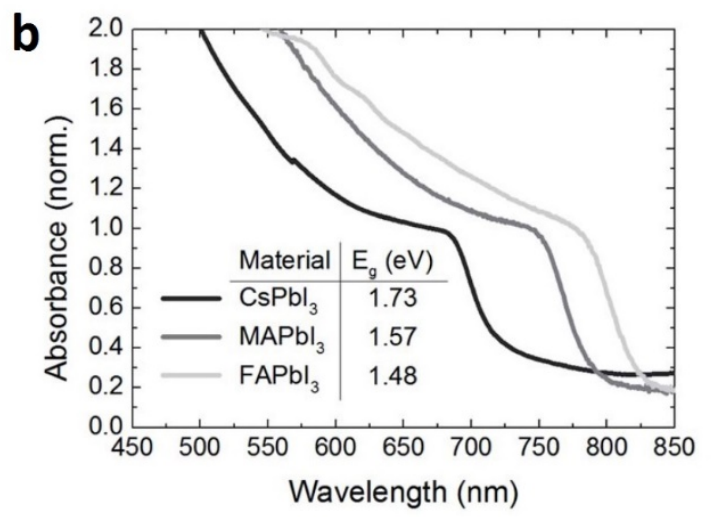

Figure 3: The influence of perovskite composition on the bandgap energy. (a) Bandgap energy change for $\mathrm{CH}_{3} \mathrm{NH}_{3} \mathrm{~Pb}\left(\mathrm{I}_{1-\mathrm{x}} \mathrm{Br} \mathrm{r}_{3}\right.$ as a function of $\mathrm{x}$. (b) bandgap and absorbance change for $\mathrm{APb} \mathrm{l}_{3}$ perovskites where, $\mathrm{A}$ being cesium (Cs), methylammonium (MA) or formamidinium (FA). Adapted with permission from (Eperon et al. 2014) and (Noh et al. 2013). ${ }^{\odot}$ 2013, American Chemical Society, and 2014, Royal Society of Chemistry

Solid-state hole transport material (HTM) was first used in DSCS as a substitute to liquid electrolyte and it exhibited increase in $\mathrm{V}_{\text {oc }}$ of the device because of their high redox potential. Moreover, the aggressive liquid electrolyte was not quite compatible with perovskites materials, leading to fast degradation of the device. In contrast, solid-state HTM had shown improvements in the stability of PSCs (Kim et al. 2012). Perhaps the most common HTM used in perovskite-sensitized cells is spiro-OMeTAD which has resulted devices with PCE reaching to $19 \%$ (Zhou et al. 2014). A high conductive HTM, reduces the series resistance and improves the fill factor of the cell (Lee et al. 2012). For example, Seok et al. reported improvement in 
$V_{\text {oc }}$ and fill factor when replacing spiro-OMeTAD $\left(12.7 \Omega . \mathrm{cm}^{2}\right)$ with polymeric PTAA , polytriarylamine, $\left(5.4 \Omega . \mathrm{cm}^{2}\right)$ hole conductor (Heo et al. 2013).

To date, various approaches were applied to construct perovskite solar cells. These include substituting traditional $\mathrm{TiO}_{2}$ photoanode with $\mathrm{Al}_{2} \mathrm{O}_{3}$ (Carnie et al. 2013, Edri et al. 2014, Lee et al. 2012), $\mathrm{ZrO}_{2}$ (Bi et al. 2013), or $\mathrm{ZnO}_{2}$ nanorod (Kumar et al. 2013, Son et al. 2014), as well as application of different organo halide perovskite such as common $\mathrm{CH}_{3} \mathrm{NH}_{3} \mathrm{Pbl}_{3}$ (Kim et al. 2013, Jeon et al. 2014, Liu and Kelly 2014, Qin et al. 2014), $\mathrm{CH}\left(\mathrm{NH}_{2}\right)_{2} \mathrm{Pbl}_{3}$ (Koh et al. 2014, Eperon et al. 2014), or $\mathrm{CH}_{3} \mathrm{NH}_{3} \mathrm{Snl}_{3}$ (Hao et al. 2014, Noel et al. 2014). Moreover, diverse fabrication routes of sequential deposition (Burschka et al. 2013, Zheng et al. 2014), vacuum deposition (Liu, Johnston, and Snaith 2013), and vapor-assisted deposition (Chen et al. 2014), provides a wide range of process temperature.

\section{Commercialization and stability challenges}

To date, the highest PCE of perovskite sensitized solar cells were reached with Pb-based perovskite light absorbers. Taking into account the toxic nature of lead and regulation related to material restriction laws, perhaps the major challenge is to replace lead with non-toxic, environmental friendly substances such as tin (Sn). Fabricated Sn-based PSCs have reached $6.4 \%$ conversion efficiency (Noel et al. 2014) which comparing to Pb-based devices, are way less efficient. Moreover, tin halide perovskites such as $\mathrm{CH}_{3} \mathrm{NH}_{3} \mathrm{Snl}_{3}$ and $\mathrm{CH}\left(\mathrm{NH}_{2}\right)_{2} \mathrm{Snl}_{3}$ crystal structure suffers from $\mathrm{Sn}^{2+} / \mathrm{Sn}^{4+}$ conversion. In which, they display n-type semiconductor behavior at their 2+ oxidation state, while accommodated $\mathrm{Sn}^{4+}$ centers results in self doping and acting as p-type metal-like material (Stoumpos, Malliakas, and Kanatzidis 2013). Therefore, the stability of these type of device remain as a challenge until reaching more advanced sealing techniques (Hao et al. 2014).

The current lead-based PSCs are reported to be sensitive to humidity and oxygen(Noh et al. 2013). Additionally, degradation issues under ultraviolet exposure was reported for mesoporous $\mathrm{TiO}_{2}$ structured lead-based devices (Leijtens et al. 2013). Overcoming these challenges is only possible through degradation mechanisms study of all components of the device.

In terms of cost, most of the component of the perovskite cells are relatively cheap. The main cost is related to FTO-coated glass substrates and gold counter electrode. However, the Au contact could be replaced by printable carbon counter electrode, to decrease of these costs (Ku et al. 2013). The production process is mostly done through cost-effective techniques such as spin-coating and screen-printing which makes these devices a promising candidate for future efficient photovoltaic industry. Graetzel et al. estimated the energy payback time of less than one year for dye-sensitized solar cells (Graetzel et al. 2012). Assuming a similar payback time approach for PSCs, reveals another advantage of these devices comparing to silicon solar cells with three years of payback (Boix et al. 2014).

The stability issue of the perovskite solar cells were not studied in details. Clearly, the research has focused on improving the performance of the device rather than paying attention to its long-term stability. Although there are some reported stable devices, but the degradation mechanisms are not well understood. Some studies stated, perovskite material as the major oxygen or UV light sensitive material, while some others identified HTM as the source of the stability issue of these photovoltaic cells.

Burschka et al. have examined long-term stability of an encapsulated (at argon atmosphere) cell with $\mathrm{TiO}_{2} / \mathrm{CH}_{3} \mathrm{NH}_{3} \mathrm{Pbl}_{3} /$ spiro-OMeTAD/Au configuration, at $45^{\circ} \mathrm{C}$ and $100 \mathrm{~mW} . \mathrm{cm}^{-2}$ light intensity for 500 hours. They reported 20 \% loss in PCE and small decay in $\mathrm{V}_{\text {oc }}$ and fill factor 
(FF) while the $J_{s c}$ remained stable. The stable $J_{s c}$ was indicating no photodegradation in perovskite sensitizer and decays was associated to shunt resistance decrease (Burschka et al. 2013).

A non-encapsulated $\mathrm{HTM}$-free cell with $\mathrm{TiO}_{2} / \mathrm{ZrO}_{2} / \mathrm{CH}_{3} \mathrm{NH}_{3} \mathrm{Pbl}_{3} / \mathrm{C}$ structure was tested for 840 hours at room temperature in the dark. The initial PCE of the device was around $6.5 \%$ and it stayed unchanged after stability experiment and even no notable change in the other characteristics of the cell (Ku et al. 2013).

Snaith et al. reveled a UV sensitive behavior for $\mathrm{TiO}_{2} / \mathrm{CH}_{3} \mathrm{NH}_{3} \mathrm{Pbl}_{3-\mathrm{x}} \mathrm{Cl} / \mathrm{s} /$ siro-OMeTAD/Au cell, which they stated to be attributed to light desorption of surface-adsorbed oxygen. The degradation issue could be decelerated through using UV filter and encapsulation. However, replacing $\mathrm{TiO}_{2}$ with $\mathrm{Al}_{2} \mathrm{O}_{3}$ has solved the UV issue and showed relatively 1,000 hour stable performance for the cell at $40^{\circ} \mathrm{C}$ and $76.5 \mathrm{~mW} . \mathrm{cm}^{-2}$ light intensity (Leijtens et al. 2013).

A series of non-sealed perovskite solar cells with $\mathrm{TiO}_{2} / \mathrm{CH}_{3} \mathrm{NH}_{3} \mathrm{~Pb}\left(\mathrm{I}_{1-\mathrm{x}} \mathrm{Br}{ }_{\mathrm{x}}\right)_{3} / \mathrm{PTAA} / \mathrm{Au}$ structure, were exposed to $35 \%$ humidity for 22 days at room temperature, to study their degradation behavior. While cells with no $\mathrm{Br}$, or low fraction of $\mathrm{Br}(\mathrm{X}=0,0.06)$ had higher PCE (ca. $11 \%)$, they acted absolutely unstable to humidity and lost $60 \%$ of their initial conversion efficiency. In contrast, device with slightly higher $\mathrm{Br}$ content $(X=0.2,0.29)$ retained their initial conversion efficiency (ca. $9.2 \%$ ) along the test (Noh et al. 2013).

While most the of non-encapsulated devices consist of $\mathrm{CH}_{3} \mathrm{NH}_{3} \mathrm{Pbl}_{3}$ exhibited stability issue, Ito et al. explored copper(I) thiocynate (CuSCN) as $\mathrm{HTM}$ in a device with $\mathrm{TiO}_{2} / \mathrm{CH}_{3} \mathrm{NH}_{3} \mathrm{Pbl}_{3}$ and reported better stability comparing to cells constructed with spiro-OMeTAD and PTAA based. They indicated that humidity effects are mainly related to HTM (or the interface of the perovskite and hole-transport material) rather than $\mathrm{CH}_{3} \mathrm{NH}_{3} \mathrm{Pbl}_{3}$ itself (Ito et al. 2014).

A similar approach was applied by Park et al. to study 1,000 hour performance of devices with $\mathrm{TiO}_{2} / \mathrm{CH}_{3} \mathrm{NH}_{3} \mathrm{Pbl}_{3} / \mathrm{HTM} / \mathrm{Au}$ configuration to investigate the influence of $20 \%$ humidity on three different HTMs. These hole-transport materials were P3HT (poly(3-hexylthiophene-2,5diyl)), PDPPDBTE (poly[2,5-bis(2-decyldodecyl)-pyr-rolo[3,4-c]pyrole-1,4(2H,5H)-dione-(E)1,2-di(2,20bithiophen-5-yl)-ethene], and spiro-OMeTAD. They concluded that cell with spiroOMeTAD lost $28 \%$ of its initial PCE while P3HT and PDPPDBTE cells maintained their PCE over the aging test. The excellent stability of polymer-based perovskite cells, is due to hydrophobic nature of these materials which prevents water from penetrating to perovskite surface (Kwon et al. 2014).

Recently, the study of HTM effect on the stability of perovskite solar cells, have begun to attract more attention (Zhang, Liu, et al. 2015, Zhang, Lyu, et al. 2015, Yeo et al. 2015, Christians, Miranda Herrera, and Kamat 2015, Guarnera et al. 2015, Misra et al. 2014, Mei et al. 2014). Nonetheless, most of these studies are testing low efficient ( $<10 \%)$ cells which are not quite suitable for commercialization purposes. Some of these studies are only considering humidity exposure test which are not proper for outdoor objectives. For outdoor application, an aging test should include temperature, humidity and light exposure.

In this challenge, two notable achievements have reached for stable PSCs with conversion efficiencies higher than $12 \%$. Snaith et al. used a buffer layer of $\mathrm{Al}_{2} \mathrm{O}_{3}$ nanoparticles between perovskite and HTM which increased both PCE and stability of the cell. A sealed device with $\mathrm{TiO}_{2} / \mathrm{CH}_{3} \mathrm{NH}_{3} \mathrm{Pbl}_{3-\mathrm{x}} \mathrm{Cl}_{\mathrm{x}} / \mathrm{Al}_{2} \mathrm{O}_{3} /$ spiro-OMeTAD/Au structure were exposed to light illumination equal to one sun, for 350 hours. The initial $13 \%$ PCE of the device was slightly changed after the aging test, while a similar device without buffer layer have lost $50 \%$ of its PCE (Guarnera et al. 2015). Mei et al. have fabricated an $\mathrm{HTM}$-free cell consisting of $\mathrm{TiO}_{2} / \mathrm{ZrO}_{2} /(5-\mathrm{AVA})_{\mathrm{x}}(\mathrm{MA})_{1-}$ 
${ }_{x} \mathrm{Pbl}_{3} / \mathrm{C}$ (where, $\mathrm{MA}=\mathrm{CH}_{3} \mathrm{NH}_{3}$, and 5-AVA $=\mathrm{HOOC}\left(\mathrm{CH}_{2}\right)_{4} \mathrm{NH}_{3}$ ). Non-encapsulated cell with 12.8 $\%$ of this study, illustrated a remarkable stability over 1008 hours of $100 \mathrm{~mW} . \mathrm{cm}^{-2}$ light exposure at room temperature. This excellent stability behavior is attributed to protection provided by thick carbon counter electrode $(10 \mu \mathrm{m})$ which is acting as water-retaining layer (Mei et al. 2014).

\section{Conclusions}

The most efficient perovskite solar cells are constructed with $\mathrm{CH}_{3} \mathrm{NH}_{3} \mathrm{Pbl}_{3}$ and spiro-OMeTAD and the main long-term stability issue of PSCs are found to be related to these two main components of the device. Some reports related stability issue to spiro-OMeTAD, and tried to replace it with polymeric materials (e.g., PTAA, P3HT, and PDPPDBTE) which they seem to be suitable alternatives. Additionally, HTM-free cells exhibited excellent stabilities when used with thick back contacts such as carbon. Therefore, these two strategies seems to be in the front line for reaching stable non-sealed cells. In contrast, an airtight encapsulation could solve many related humidity issue of these photovoltaic devices without modifying efficient stateof-the-art components. Hence, another trend of research would be to development a decent encapsulation technology.

The current $\mathrm{Pb}$-based state-of-the-art perovskite solar cells are having a hazardous heavy metal drawback similar to CdTe solar cells. European Union Restriction on Hazardous Substances (RoHS) made an exception for CdTe, perhaps the same approach may be considered for PSCs as well. However, production capacity of 1,000 GW per year could be reached by less than 10,000 tons of $\mathrm{Pb}$ which is much lower lead-content comparing to 4 million tons per year needed for lead-acid batteries (Hodes 2013).

Long-term stability and lead content, were found to be the largest drawbacks of perovskite solar cells. Study of the degradation mechanism of the device would result in cells with enhanced long-term stability. In addition, further research is required in order to find a suitable alternatives to replace $\mathrm{Pb}$ with non-toxic substances.

\section{References}

Asghar, M. I., K. Miettunen, J. Halme, P. Vahermaa, M. Toivola, K. Aitola, and P. Lund. 2010. "Review of stability for advanced dye solar cells." Energy and Environmental Science no. 3 (4):418-426.

Bach, U., D. Lupo, P. Comte, J. E. Moser, F. Weissörtel, J. Salbeck, H. Spreitzer, and M. Grätzel. 1998. "Solid-state dye-sensitized mesoporous TiO2 solar cells with high photon-to-electron conversion efficiencies." Nature no. 395 (6702):583-585.

Ball, J. M., M. M. Lee, A. Hey, and H. J. Snaith. 2013. "Low-temperature processed mesosuperstructured to thin-film perovskite solar cells." Energy and Environmental Science no. $6(6): 1739-1743$.

Bi, Dongqin, Soo-Jin Moon, Leif Haggman, Gerrit Boschloo, Lei Yang, Erik M. J. Johansson, Mohammad K. Nazeeruddin, Michael Gratzel, and Anders Hagfeldt. 2013. "Using a twostep deposition technique to prepare perovskite $(\mathrm{CH} 3 \mathrm{NH} 3 \mathrm{PbI} 3)$ for thin film solar cells based on ZrO2 and TiO2 mesostructures." RSC Advances no. 3 (41):18762-18766. DOI: 10.1039/C3RA43228A.

Boix, P. P., K. Nonomura, N. Mathews, and S. G. Mhaisalkar. 2014. "Current progress and future perspectives for organic/inorganic perovskite solar cells." Materials Today no. 17 (1):16-23. 
Britt, J., and C. Ferekides. 1993. "Thin-film CdS/CdTe solar cell with $15.8 \%$ efficiency." Applied Physics Letters no. 62 (22):2851-2852.

Burschka, J., N. Pellet, S. J. Moon, R. Humphry-Baker, P. Gao, M. K. Nazeeruddin, and M. Grätzel. 2013. "Sequential deposition as a route to high-performance perovskite-sensitized solar cells." Nature no. 499 (7458):316-319.

Cai, N., S. J. Moon, L. Cevey-Ha, T. Moehl, R. Humphry-Baker, P. Wang, S. M. Zakeeruddin, and M. Grätzel. 2011. "An organic D- $\pi-A$ dye for record efficiency solid-state sensitized heterojunction solar cells." Nano Letters no. 11 (4):1452-1456.

Carnie, M. J., C. Charbonneau, M. L. Davies, J. Troughton, T. M. Watson, K. Wojciechowski, H. Snaith, and D. A. Worsley. 2013. "A one-step low temperature processing route for organolead halide perovskite solar cells." Chemical Communications no. 49 (72):7893-7895.

Chen, Q., H. Zhou, Z. Hong, S. Luo, H. S. Duan, H. H. Wang, Y. Liu, G. Li, and Y. Yang. 2014. "Planar heterojunction perovskite solar cells via vapor-assisted solution process." Journal of the American Chemical Society no. 136 (2):622-625.

Christians, Jeffrey A., Pierre A. Miranda Herrera, and Prashant V. Kamat. 2015. "Transformation of the Excited State and Photovoltaic Efficiency of CH3NH3Pbl3 Perovskite upon Controlled Exposure to Humidified Air." Journal of the American Chemical Society. DOI: 10.1021/ja511132a.

Edri, E., S. Kirmayer, M. Kulbak, G. Hodes, and D. Cahen. 2014. "Chloride inclusion and hole transport material doping to improve methyl ammonium lead bromide perovskite-based high open-circuit voltage solar cells." Journal of Physical Chemistry Letters no. 5 (3):429-433.

Eperon, G. E., S. D. Stranks, C. Menelaou, M. B. Johnston, L. M. Herz, and H. J. Snaith. 2014. "Formamidinium lead trihalide: A broadly tunable perovskite for efficient planar heterojunction solar cells." Energy and Environmental Science no. 7 (3):982-988.

Gonzalez-Pedro, V., E. J. Juarez-Perez, W. S. Arsyad, E. M. Barea, F. Fabregat-Santiago, I. MoraSero, and J. Bisquert. 2014. "General working principles of $\mathrm{CH} 3 \mathrm{NH} 3 \mathrm{PbX} 3$ perovskite solar cells." Nano Letters no. 14 (2):888-893.

Graetzel, M., R. A. J. Janssen, D. B. Mitzi, and E. H. Sargent. 2012. "Materials interface engineering for solution-processed photovoltaics." Nature no. 488 (7411):304-312.

Green, M. A., K. Emery, Y. Hishikawa, W. Warta, and E. D. Dunlop. 2015. "Solar cell efficiency tables (Version 45)." Progress in Photovoltaics: Research and Applications no. 23 (1):1-9.

Green, Martin A., Anita Ho-Baillie, and Henry J. Snaith. 2014. "The emergence of perovskite solar cells." Nature Photonics no. 8 (7):506-514. DOI: 10.1038/nphoton.2014.134.

Guarnera, Simone, Antonio Abate, Wei Zhang, Jamie M. Foster, Giles Richardson, Annamaria Petrozza, and Henry J. Snaith. 2015. "Improving the Long-Term Stability of Perovskite Solar Cells with a Porous Al2O3 Buffer Layer." The Journal of Physical Chemistry Letters:432-437. DOI: 10.1021/jz502703p.

Hagfeldt, A., G. Boschloo, L. Sun, L. Kloo, and H. Pettersson. 2010. "Dye-sensitized solar cells." Chemical Reviews no. 110 (11):6595-6663.

Hao, F., C. C. Stoumpos, D. H. Cao, R. P. H. Chang, and M. G. Kanatzidis. 2014. "Lead-free solidstate organic-inorganic halide perovskite solar cells." Nature Photonics no. 8 (6):489-494.

Heo, J. H., S. H. Im, J. H. Noh, T. N. Mandal, C. S. Lim, J. A. Chang, Y. H. Lee, H. J. Kim, A. Sarkar, M. K. Nazeeruddin, M. Grätzel, and S. I. Seok. 2013. "Efficient inorganic-organic hybrid heterojunction solar cells containing perovskite compound and polymeric hole conductors." Nature Photonics no. 7 (6):486-491. 
Hodes, G. 2013. "Perovskite-based solar cells." Science no. 342 (6156):317-318.

Im, J. H., J. Chung, S. J. Kim, and N. G. Park. 2012. "Synthesis, structure, and photovoltaic property of a nanocrystalline $2 \mathrm{H}$ perovskite-type novel sensitizer ( $\mathrm{CH} 3 \mathrm{CH} 2 \mathrm{NH} 3) \mathrm{Pbl} 3 . "$ Nanoscale Research Letters no. 7:1-14.

Ito, S., S. Tanaka, H. Vahlman, H. Nishino, K. Manabe, and P. Lund. 2014. "Carbon-doublebond-free printed solar cells from $\mathrm{TiO} 2 / \mathrm{CH} 3 \mathrm{NH} 3 \mathrm{Pbl} / \mathrm{CuSCN} / \mathrm{Au}$ : Structural control and photoaging effects." ChemPhysChem no. 15 (6):1194-1200.

Jackson, P., D. Hariskos, E. Lotter, S. Paetel, R. Wuerz, R. Menner, W. Wischmann, and M. Powalla. 2011. "New world record efficiency for $\mathrm{Cu}(\mathrm{In}, \mathrm{Ga}) \mathrm{Se} 2$ thin-film solar cells beyond 20\%." Progress in Photovoltaics: Research and Applications no. 19 (7):894-897.

Jeon, Nam Joong, Jun Hong Noh, Young Chan Kim, Woon Seok Yang, Seungchan Ryu, and Sang II Seok. 2014. "Solvent engineering for high-performance inorganic-organic hybrid perovskite solar cells." Nat Mater no. 13 (9):897-903. DOI: 10.1038/nmat4014.

Kim, H. S., C. R. Lee, J. H. Im, K. B. Lee, T. Moehl, A. Marchioro, S. J. Moon, R. Humphry-Baker, J. H. Yum, J. E. Moser, M. Gratzel, and N. G. Park. 2012. "Lead iodide perovskite sensitized all-solid-state submicron thin film mesoscopic solar cell with efficiency exceeding 9\%." Sci Rep no. 2:591. DOI: 10.1038/srep00591.

Kim, H. S., J. W. Lee, N. Yantara, P. P. Boix, S. A. Kulkarni, S. Mhaisalkar, M. Grätzel, and N. G. Park. 2013. "High efficiency solid-state sensitized solar cell-based on submicrometer rutile TiO2 nanorod and CH3NH3PbI3 perovskite sensitizer." Nano Letters no. 13 (6):2412-2417.

Koh, T. M., K. Fu, Y. Fang, S. Chen, T. C. Sum, N. Mathews, S. G. Mhaisalkar, P. P. Boix, and T. Baikie. 2014. "Formamidinium-containing metal-halide: An alternative material for near-IR absorption perovskite solar cells." Journal of Physical Chemistry C no. 118 (30):16458-16462.

Kojima, A., K. Teshima, Y. Shirai, and T. Miyasaka. 2009. "Organometal halide perovskites as visible-light sensitizers for photovoltaic cells." Journal of the American Chemical Society no. 131 (17):6050-6051.

Ku, Z., Y. Rong, M. Xu, T. Liu, and H. Han. 2013. "Full printable processed mesoscopic CH3 NH3 PbI 3 /TiO2 heterojunction solar cells with carbon counter electrode." Scientific Reports no. 3.

Kumar, M. H., N. Yantara, S. Dharani, M. Graetzel, S. Mhaisalkar, P. P. Boix, and N. Mathews. 2013. "Flexible, low-temperature, solution processed ZnO-based perovskite solid state solar cells." Chemical Communications no. 49 (94):11089-11091.

Kwon, Y. S., J. Lim, H. J. Yun, Y. H. Kim, and T. Park. 2014. "A diketopyrrolopyrrole-containing hole transporting conjugated polymer for use in efficient stable organic-inorganic hybrid solar cells based on a perovskite." Energy and Environmental Science no. 7 (4):1454-1460.

Lee, M. M., J. Teuscher, T. Miyasaka, T. N. Murakami, and H. J. Snaith. 2012. "Efficient hybrid solar cells based on meso-superstructured organometal halide perovskites." Science no. 338 (6107):643-647.

Leijtens, T., G. E. Eperon, S. Pathak, A. Abate, M. M. Lee, and H. J. Snaith. 2013. "Overcoming ultraviolet light instability of sensitized $\mathrm{TiO}(2)$ with meso-superstructured organometal trihalide perovskite solar cells." Nat Commun no. 4:2885. DOI: 10.1038/ncomms3885.

Liu, D., and T. L. Kelly. 2014. "Perovskite solar cells with a planar heterojunction structure prepared using room-temperature solution processing techniques." Nature Photonics no. $8(2): 133-138$.

Liu, M., M. B. Johnston, and H. J. Snaith. 2013. "Efficient planar heterojunction perovskite solar cells by vapour deposition." Nature no. 501 (7467):395-398. 
Marchioro, A., J. Teuscher, D. Friedrich, M. Kunst, R. Van De Krol, T. Moehl, M. Grätzel, and J. E. Moser. 2014. "Unravelling the mechanism of photoinduced charge transfer processes in lead iodide perovskite solar cells." Nature Photonics no. 8 (3):250-255.

Mathew, S., A. Yella, P. Gao, R. Humphry-Baker, B. F. E. Curchod, N. Ashari-Astani, I. Tavernelli, U. Rothlisberger, M. K. Nazeeruddin, and M. Grätzel. 2014. "Dye-sensitized solar cells with $13 \%$ efficiency achieved through the molecular engineering of porphyrin sensitizers." Nature Chemistry no. 6 (3):242-247.

Mei, A., X. Li, L. Liu, Z. Ku, T. Liu, Y. Rong, M. Xu, M. Hu, J. Chen, Y. Yang, M. Grätzel, and H. Han. 2014. "A hole-conductor-free, fully printable mesoscopic perovskite solar cell with high stability." Science no. 345 (6194):295-298.

Meillaud, F., A. Shah, C. Droz, E. Vallat-Sauvain, and C. Miazza. 2006. "Efficiency limits for single-junction and tandem solar cells." Solar Energy Materials and Solar Cells no. 90 (1819):2952-2959.

Misra, Ravi K., Sigalit Aharon, Baili Li, Dmitri Mogilyansky, Iris Visoly-Fisher, Lioz Etgar, and Eugene A. Katz. 2014. "Temperature- and Component-Dependent Degradation of Perovskite Photovoltaic Materials under Concentrated Sunlight." The Journal of Physical Chemistry Letters:326-330. DOI: 10.1021/jz502642b.

Mitzi, D. B. 1996. "Synthesis, crystal structure, and optical and thermal properties of (C 4H9NH3)2MI4 (M = Ge, Sn, Pb)." Chemistry of Materials no. 8 (3):791-800.

Noel, Nakita K., Samuel D. Stranks, Antonio Abate, Christian Wehrenfennig, Simone Guarnera, Amir-Abbas Haghighirad, Aditya Sadhanala, Giles E. Eperon, Sandeep K. Pathak, Michael B. Johnston, Annamaria Petrozza, Laura M. Herz, and Henry J. Snaith. 2014. "Lead-free organic-inorganic tin halide perovskites for photovoltaic applications." Energy \& Environmental Science no. 7 (9):3061. DOI: 10.1039/c4ee01076k.

Noh, J. H., S. H. Im, J. H. Heo, T. N. Mandal, and S. I. Seok. 2013. "Chemical management for colorful, efficient, and stable inorganic-organic hybrid nanostructured solar cells." Nano Letters no. 13 (4):1764-1769.

O'Regan, B., and M. Grätzel. 1991. "A low-cost, high-efficiency solar cell based on dyesensitized colloidal TiO2 films." Nature no. 353 (6346):737-740.

Qin, P., S. Tanaka, S. Ito, N. Tetreault, K. Manabe, H. Nishino, M. K. Nazeeruddin, and M. Grätzel. 2014. "Inorganic hole conductor-based lead halide perovskite solar cells with 12.4\% conversion efficiency." Nature Communications no. 5.

Ribeiro, F., J. MaçAira, R. Cruz, J. Gabriel, L. Andrade, and A. Mendes. 2012. "Laser assisted glass frit sealing of dye-sensitized solar cells." Solar Energy Materials and Solar Cells no. 96 (1):43-49.

Son, D. Y., J. H. Im, H. S. Kim, and N. G. Park. 2014. "11\% efficient perovskite solar cell based on ZnO nanorods: An effective charge collection system." Journal of Physical Chemistry $C$ no. 118 (30):16567-16573.

Stoumpos, C. C., C. D. Malliakas, and M. G. Kanatzidis. 2013. "Semiconducting tin and lead iodide perovskites with organic cations: Phase transitions, high mobilities, and nearinfrared photoluminescent properties." Inorganic Chemistry no. 52 (15):9019-9038.

Xing, G., N. Mathews, S. Sun, S. S. Lim, Y. M. Lam, M. Grä̈zel, S. Mhaisalkar, and T. C. Sum. 2013. "Long-range balanced electron-and hole-transport lengths in organic-inorganic CH3NH3Pbl3." Science no. 342 (6156):344-347. 
Yeo, J. S., R. Kang, S. Lee, Y. J. Jeon, N. Myoung, C. L. Lee, D. Y. Kim, J. M. Yun, Y. H. Seo, S. S. Kim, and S. I. Na. 2015. "Highly efficient and stable planar perovskite solar cells with reduced graphene oxide nanosheets as electrode interlayer." Nano Energy no. 12:96-104.

Zhang, M., M. Lyu, H. Yu, J. H. Yun, Q. Wang, and L. Wang. 2015. "Stable and low-cost mesoscopic $\mathrm{CH} 3 \mathrm{NH} 3 \mathrm{~Pb} / 2 \mathrm{Br}$ perovskite solar cells by using a thin poly(3-hexylthiophene) layer as a hole transporter." Chemistry - A European Journal no. 21 (1):434-439.

Zhang, Y., W. Liu, F. Tan, and Y. Gu. 2015. "The essential role of the poly(3-hexylthiophene) hole transport layer in perovskite solar cells." Journal of Power Sources no. 274:1224-1230.

Zheng, L., Y. Ma, S. Chu, S. Wang, B. Qu, L. Xiao, Z. Chen, Q. Gong, Z. Wu, and X. Hou. 2014. "Improved light absorption and charge transport for perovskite solar cells with rough interfaces by sequential deposition." Nanoscale no. 6 (14):8171-8176.

Zhou, H., Q. Chen, G. Li, S. Luo, T. B. Song, H. S. Duan, Z. Hong, J. You, Y. Liu, and Y. Yang. 2014. "Interface engineering of highly efficient perovskite solar cells." Science no. 345 (6196):542546.

\section{Acknowledgments}

S. Emami and L. Andrade acknowledge European Research Council for funding within project BI-DSC - Building Integrated Dye sensitized Solar Cells (Contract Number: 321315). The authors also acknowledge Project WinDSC SI\&IDT (ref. 21539/2011) for financial support. 